\title{
Gris: metáfora, símbolo y relato en (inter)acción.
}

\section{Gris: metaphor, symbol and storytelling in (inter)action.}

DOI: $10.32870 /$ sincronia.axxv.n80.15b21

\author{
Ismael Antonio Borunda Magallanes \\ Universidad Autónoma del Estado de Morelos (MÉXICO) \\ CE: iab site@hotmail.com / ORCID: 0000-0002-7883-422X
}

Esta obra está bajo una Licencia Creative Commons Atribución-NoComercial 4.0 Internacional

Recibido: 20/03/2021

Revisado: $18 / 05 / 2021$

Aprobado: 1/06/2021

\section{RESUMEN}

Gris, videojuego español de producción independiente, explora las posibilidades expresivas de este medio creativo mediante un relato que es, por un lado, una representación simbólica del proceso psicológico de su protagonista, y, por el otro, una narración fundacional sobre la pérdida y la recuperación de la identidad. El título recurre a las herramientas expresivas de la historia del arte para construir su propuesta estética; en particular, se coloca categóricamente en la línea del surrealismo como corriente artística. El análisis de este conjunto de elementos se realiza a partir de nociones fundamentales de retórica y poética, retomando a autoras como Helena Beristáin y Carmen Bobes, y la hermenéutica narrativa de Paul Ricoeur, así como aportes teóricos que permiten tender puentes de análisis entre la literatura y las artes visuales.

Palabras claves: Videojuegos. Narrativa. Arte. Poética.

\section{ABSTRACT}

Gris, an independent Spanish video game, explores the expressive possibilities of this creative medium through a story that is, on one hand, a symbolic representation of the psychological process of the protagonist, and, on the other hand, a foundational narrative about the loss and recovery of identity. This title employs the expressive tools of the history 
of art to build its aesthetic proposal; in particular, it is categorically placed in the line of surrealism as an artistic current. The analysis of this elements is realized through fundamental notions of rhetoric and poetics, referencing authors such as Helena Beristáin and Carmen Bobes, and the narrative hermeneutics of Paul Ricoeur, as well as theoretical perspectives that allow building bridges of analysis between literature and the visual arts.

Keywords: Video games. Narrative. Art. Poetics.

\section{Introducción}

Los videojuegos son un medio de expresión capaz de articular narraciones a través de las herramientas discursivas que le otorgan sus características técnicas; en particular, la capacidad de integrar las acciones concretas de los jugadores a la narración y, más aún, que el desenvolvimiento de esa narración está determinado por tales acciones. A su vez, su carácter eminentemente visual permite retomar las herramientas discursivas desarrolladas por las artes visuales a lo largo de su historia.

Gris (2018) es un videojuego de estética surrealista desarrollado por el equipo español Nomada Studio, situado en Barcelona. El juego cuenta la historia de una mujer que ha perdido su voz, y con ello la habilidad de cantar, lo cual desencadena en ella una profunda depresión, y tal circunstancia la llevará por una travesía metafísica de autodescubrimiento. Se cataloga como un juego de plataformas en dos dimensiones que implementa elementos de acertijos y pruebas de destreza, con una dirección artística inspirada por algunas de las vanguardias pictóricas de principios del siglo XX, así como referencias a la historia de la animación y el cine. Durante la ceremonia de los Game Awards $2019^{1}$ recibió el premio en la categoría de juego de impacto (games for impact), que se otorga a los juegos que resaltan aspectos de desarrollo social o cultural, como la inclusión de personas de distintos orígenes étnicos y la visibilización de enfermedades mentales.

\footnotetext{
${ }^{1}$ Desde 2014, los Game Awards es la ceremonia de premiación de videojuegos como medio más ampliamente difundida entre la audiencia que constituyen los consumidores de la industria, aunque no son los únicos, pues existen también reconocimientos dados por la Developers Game Conference y el Independent Games Festival. La votación para determinar a los títulos nominados y ganadores la determinan diseñadores, desarrolladores, críticos y periodistas de la insdustria, así como una votación pública realizada por Internet.
} 
El juego recurre a la metáfora como tropo poético para la configuración de su sentido. Cuando se dice que en este juego las acciones del personaje central se comportan como metáforas, se refiere a esta noción como eminentemente retórica-poética. En tanto las acciones llevadas a cabo en el mundo de un juego, como las de los agentes en una narrativa literaria convencional, comportan sentido, tal sentido puede manifestarse de manera metafórica, una yuxtaposición de dos realidades semánticas.

El marcó de análisis con el que se realiza el presente acercamiento es, por un lado, una fundamentación de este carácter metafórico como propio y pertinente de algunas obras visuales, y su relación con la poética descrita desde la literatura como disciplina académica. Helena Beristáin, en su Diccionario de retórica y poética, en el que recoge nociones desde Aristóteles hasta Roman Jakobson, identifica a la metáfora como concepto y la relaciona con dinámicas de significación que este juego pretende replicar:

En todas las formas que adopta la metáfora hay una idea que se predica acerca de otra. A veces está implícita [...] y a veces está explícita, cuando hay verbo.

Las metáforas que relacionan elementos simbólicos o míticos (metáfora mitológica), elementos ya metafóricos, ofrecen mayor resonancia que las que relacionan elementos de otra naturaleza como los visuales, táctiles, etc. (1995, p.316)

En el caso de Gris, (2018) el relato narrado se constituye a su vez como una alegoría, de las que también Beristáin explica: "en la alegoría, para expresar poéticamente un pensamiento, a partir de comparaciones o metáforas, se establece una correspondencia entre elementos imaginarios" (1995, p.36). Gris elabora redes de significaciones metafóricas que enarbolan una alegoría, como en la narrativa los distintos episodios temporales se constituyen en un sentido configurativo que permea todo el relato.

Por otro lado, se recurre también a la hermenéutica narrativa de Paul Ricoeur, en particular a la idea planteada en Tiempo y Narración (2004), la triple mimesis, por la que se explica que el proceso de articulación de una narrativa parte de una comprensión general del mundo por parte del 
autor o creador, se constituye como una estructura de sentido mediada por una materialidad, una novela, una a película o un videojuego, y, finalmente, coloca al lector (o espectador, o jugador) en un espacio de interpretación que le permite entender al relato como una posibilidad de ser y, a su vez, observarse a sí mismo en ese espacio de posibilidad que es el mundo del narrativo.

\section{Metáforas entre el verso y el pixel}

Los juegos de plataformas en dos dimensiones son uno de los géneros más emblemáticos de los videojuegos como medio. En general, consisten en la superación de pruebas de destreza motriz para llevar al avatar ${ }^{2}$ de un punto a otro, sobreponiéndose a obstáculos y enemigos, desplazándose de manera bidimensional, casi siempre de izquierda a derecha. Durante los años ochenta y noventa, la gran mayoría de los juegos producidos para los sistemas de juego más prominentes pertenecían a esta categoría; la serie Super Mario Bros. es el ejemplo más reconocido de aquella tendencia.

Gris recurre a los elementos de este género para articular muy claramente una tesis discursiva con respecto de la depresión emocional alrededor de la noción de duelo, lo que a su vez se relaciona con la pérdida de identidad como fenómeno psicológico. Esto es planteado de manera metafórica a partir de los recursos audiovisuales, principalmente, así como de las acciones que debe realizar el jugador dadas las mecánicas y reglas del juego. Todo ello configura una narración que lleva al personaje principal por un recorrido de redescubrimiento personal, lo que se figura simbólicamente mediante el desplazamiento a través de espacios fantásticos oníricos. Dado el carácter estético de este conjunto de elementos iconográficos, la articulación de sentido es trazada por las estrategias estéticas del surrealismo como estilo artístico.

Para decirlo más llanamente, Gris es un juego surrealista. No existe en la práctica cotidiana de la industria una categorización con un criterio de estilo artístico; rara vez se encuentran descripciones que aludan a terminología de la historia del arte para esbozar las características de un

\footnotetext{
${ }^{2}$ Avatar es el término técnico usado hacia dentro del ámbito del diseño de videojuegos con el que se designa al personaje o entidad por el que el jugador manifiesta sus acciones en el mundo del juego. Mario, el protagonista de la serie de Super Mario Bros., de Nintendo, es uno de los ejemplos más emblemáticos.
} 
juego. $Y$ no es que no haya juegos con elementos de la historia del arte; todo lo contrario, pero es cierto que en el ámbito de los videojuegos como medio e industria no se reconoce una línea de juegos surrealistas a la que Gris pudiera integrarse.

En ese sentido, lo que hace surrealista a este título no es formar parte de una tendencia concreta, sino tomar para sí las herramientas del surrealismo como conjunto de elementos estéticos y significativos, del que han formado parte tanto la poesía como la pintura, además de obras del cine, la narrativa literaria, el teatro y la música. De hecho, Conrad Roset, artista visual español y director creativo del juego, nunca menciona que la estética de Gris pretenda ser surrealista, y refiere más directamente a la historia de la animación y a otros juegos independientes como inspiraciones más contundentes en su trabajo creativo ${ }^{3}$; ello, por supuesto, no niega que la categorización que se propone sea no solamente apropiada sino en especial relevante.

En Del texto a la acción, Paul Ricoeur describe las obras narrativas como "experimentos" de la realidad, en el mismo sentido que una prueba científica de laboratorio es un experimento de eventos que ocurren de manera natural en el mundo (2002, p.21). Así, la metáfora representa el núcleo tropológico del fenómeno hermenéutico en general, el espacio de posibilidad para la interpretación. Mientras la metáfora refiere a algo distinto de sí misma, en tanto figura semántica, el relato arroja verdades sobre el mundo real del que parte su autor para su construcción; esto es la mimesis I, la prefiguración.

No obstante, la metáfora es solamente un elemento individual del sistema más amplio que es el relato. Aludiendo a la noción de discurso que Ricoeur recupera de Émile Benveniste, la frase es la unidad mínima del sentido, y un conjunto de frases articula un sentido discursivo; estas frases pueden manifestarse en forma de metáforas. Así pues, en este relato hay conjuntos de metáforas que configuran un sentido.

Un rasgo fundamental de las frases metafóricas es la relación de semejanza que establecen entre sus partes. Mientras la relación de referencia entre el signo lingüístico y el objeto al que

\footnotetext{
${ }^{3}$ Declaraciones hechas durante la conferencia impartida por el autor en el Festival de Cultura Japonesa Japan Weekend de Madrid en 2019.
} 
designa es, en principio, arbitraria, la metáfora guarda una relación motivada entre referente y referencia; es decir, la metáfora implica alguna forma de analogía. Carmen Bobes, en su muy exhaustivo trabajo La metáfora, explica:

Los fundamentos ontológicos de una analogía pueden ser de semejanza entre cosas por su situación, por su naturaleza, por sus relaciones, y subjetivamente la analogía se da en la percepción que el sujeto tiene de dos realidades. La facultad de pensar por analogía permite utilizar las unidades léxicas para las relaciones metafóricas. (2004, p.119)

La semejanza intrínseca en la metáfora da por sentado un primer criterio de interpretación de ésta: la analogía. En la frase "tus dientes de perla" no existe una comparación concreta como figura retórica ni construcción sintáctica, pero sí hay una analogía ineludible entre los dos elementos capitales de la frase, dientes y perlas. Aunque el sentido de la semejanza no es explícito, la naturaleza metafórica de la frase (y ésta es evidenciada por el claro sentido figurado de la oración, pues una interpretación literal sería incoherente) demanda una interpretación analógica. Debe considerarse también que la semejanza entres las unidades léxicas puede resultar oscura, ambigua o críptica en cada caso, sobre todo en textos poéticos con una prominente intención autoral, en la que esta semejanza sea motivada por una visión individual del mundo.

Finalmente, el análisis hermenéutico admite la extensión de la metáfora como tropo lingüístico hacia otros sistemas de significación, es decir, otros lenguajes además del verbal, pues, en tanto sistemas de signos, son capaces de configurar discursos. Al describir la relación del dibujo de Pablo Picasso, Deucalión y Pirra, que ilustra un pasaje de Las metamorfosis de Ovidio, con el texto literario que lo inspira, Eduardo Peñuela expone:

En el cabello de Deucalión y del niño se recogen con ternura ondulaciones acuosas y en la melena de Pirra se preserva una especie de mojadura en la que, poéticamente, se resume la femenina humedad de un gran diluvio. Pero, con certeza, esos lugares, tiene uno que irlos ordenando para que la lectura, o el afán de lectura, encuentre los puntos en donde se localizan las conexiones del sentido. (2006, p.76) 
El artículo de Peñuela, "La metáfora visual", de la que se extrae la cita anterior, discute en general la pertinencia de pensar en las imágenes como metáforas y, más concretamente, si las imágenes se prestan con mayor soltura a la libre interpretación que los textos literarios por la aparente indeterminación del lenguaje pictórico. Peñuela determina que tal indeterminación no es inherente de un medio u otro, sino de la intención poética manifestada en cada obra. El pasaje literario en el que Picasso basa su boceto se muestra ambiguo en cuanto a su sentido para los propios personajes, pero el cuadro en sí mismo comporta una clara metáfora, lingüística y semánticamente articulada: "Todo ocurre en el dibujo, como si las formas pudiesen ser varias cosas al mismo tiempo y, con todo, esas formas poseen sus encajes, sus reglas de concordancia, sus declinaciones" (Peñuela, 2006, p.76).

Esta trascendencia de la metáfora como tropo retórico visual surge de la lingüisticidad enarbolada por su sistema de signos, visuales en este caso, lo que ha sido expuesto también por Seymour Chatman (2013) en lo que denomina la sustancia de la expresión, el "material" del que están hechos los signos, palabras, imágenes, sonidos, o el conjunto de todos ellos; y se extiende a la propia narratología en lo que identifica como la estructura semiótica del relato, la inherencia de sentido configurado como narración, independiente de su medio de expresión, cine, literatura, videojuegos y demás posibilidades.

\section{El Surrealismo en juego}

Ahora es necesario ahondar en la naturaleza de la estética surrealista. El surrealismo como vanguardia artística fundamenta su propuesta, en parte, en la representación del mundo onírico como manifestación de la realidad interna del artista. Bárbara Barreiro expone:

Los surrealistas prefirieron hacer caso omiso de la realidad y guiarse por las imágenes que sus sueños y su vigilia producían, convirtiendo a estas en imágenes reales y verdaderas de la naturaleza del sujeto. Es por esto por lo que identificamos al surrealismo como un movimiento en el que cada artista representa su propio mundo interior, sus necesidades y sus deseos más profundos. (2014, p.453) 
André Bretón en su célebre primer manifiesto propone una definición inicial, y aunque el surrealismo no depende exclusivamente de ésta en su desarrollo histórico posterior, cierto es también que este desarrollo no ha perdido de vista el espíritu estético de ese primer manifiesto. Para Bretón, el surrealismo es una suerte de irrupción de la libre asociación de ideas, imágenes y deseos el interior del artista en el mundo de la racionalidad que la cultura moderna pretende habitar:

Surrealismo: sustantivo masculino. Automatismo psíquico puro por cuyo medio se intenta expresar tanto verbalmente como por escrito, o de cualquier otro modo, el funcionamiento real del pensamiento. Dictado del pensamiento, con exclusión de todo control ejercido por la razón y al margen de cualquier preocupación estética o moral. (Bretón, 2001, p.44)

El surrealismo como propuesta estética discursiva (o sea, conscientemente articulada por una intencionalidad) incorpora también al psicoanálisis; en específico, la propuesta de Sigmund Freud que describe los sueños como manifestación simbólica del inconsciente: “Con toda justicia Freud ha centrado su análisis sobre el sueño. [...] El hombre, cuando cesa de dormir, se convierte ante todo en juguete de su memoria" (Bretón, 2001, pp.27-28). Bretón y los artistas adheridos a su propuesta llevan esta teoría psicoanalítica al plano de la expresión artística y la convierten en una libre asociación de ideas e imágenes, lo cual en sí mismo es característica no solo de los sueños sino de toda forma de pensamiento desasociada de la voluntad racional, eso que Bretón nombra automatismo psíquico.

Ni Bárbara Barreiro, en su presentación de la historia del movimiento surrealista, ni el propio André Breton hacen énfasis en las características teóricas de sus imágenes (en parte, el surrealismo fue una réplica rebelde contra toda forma de racionalización del arte), pero resulta evidente de cualquier manera que, explicadas desde una perspectiva semiótica, las imágenes oníricas del surrealismo se comportan como símbolos, sobre todo al considerar la importante influencia del 
psicoanálisis en esta vanguardia. El símbolo, como lo ha descrito C. S. Peirce, depende de una estructura de significación que trasciende al propio signo: el símbolo refiere a algo distinto de sí mismo, pero su relación con aquello no es arbitraria sino motivada cultural, histórica o intertextualmente, a la vez que el significante simbólico reclama atención sobre sí (1986, p.55). En el caso del surrealismo, los símbolos se definen también en su relación con aquello que está codificado desde el inconsciente, y que se manifiesta como una imagen onírica, imaginaria, lisérgica o esquizofrénica.

Es en esta naturaleza simbólica de las imágenes surrealistas que estriba su relación con el lenguaje metafórico. R. Wellek y A. Warren, en Teoría literaria, deliberan sobre la yuxtaposición conceptual entre la imagen, la metáfora y el símbolo (1966, p.225). Su discusión gira en torno a la lírica, pero revisan también imágenes visuales al señalar el uso de símbolos en la iconografía cristiana. Los autores concluyen que, aunque puedan señalarse diferencias notables entre los conceptos, su comportamiento como figuras del lenguaje literario siempre oscila entre esas definiciones. Las imágenes poéticas implican el entrecruzamiento de las realidades aludidas directa e indirectamente por los signos que las constituyen, como ya lo han señalado también Helena Beristáin y Carmen Bobes; y al existir este entrecruzamiento, los signos muestran un comportamiento metafórico. Los símbolos son siempre $-\mathrm{y}$ la iconografía surrealista trae este carácter metafórico al frente- un entrecruzamiento de realidades; en el caso de esta vanguardia, la realidad interna del artista y la figuración icónica por la que se le representa.

El resultado es un conjunto de estrategias discursivas que manifiestan, a través del cuadro o el poema, la relación denotativa-connotativa de la metáfora como tropo retórico. La connotación psicológica se observa entre el símbolo, imagen asociada, y aquello con lo que establece una relación de semejanza. En el surrealismo, más veces que las que no, esta semejanza se comporta como espacio vacío que demanda una interpretación basada en la analogía.

Ésta es justo la coyuntura en la que contundentemente se coloca Gris. La principal herramienta de significación de este título es la asociación simbólica tendida entre las imágenes, la 
iconografía que configura el relato audiovisual interactivo del juego, y aquello a lo que refiere en el espectro emocional.

En contraste con el surrealismo pictórico clásico, Gris recurre a una iconografía bastante simple y explícita en sí misma, aunque siempre de carácter simbólico. El motivo visual que domina la narrativa del juego es la imagen de la mujer. El avatar anónimo es claramente un personaje femenino, aunque su silueta no enfatiza nunca su cuerpo, pues usa una vestimenta amplia y holgada. El cuerpo femenino, sin embargo, aparece constantemente, conforme el avatar recorre los espacios del juego, en forma de esculturas rotas en diferentes posturas expresivas, de lamento, vulnerabilidad, reflexión o paz. Estas esculturas cumplen una doble función narrativa; son, por un lado, objetos reales en el mundo onírico del relato con los que el avatar interactúa de varias maneras (su significación dentro del mundo del juego nunca queda del todo clara, pues el espacio de esta historia tiene una naturaleza metafísica inconcreta, y no hay una razón explícita de por qué esas estatuas existen); pero son, más determinantemente, símbolos del viaje emocional del personaje principal, cuya significación está dirigida al jugador como intérprete.

En tanto símbolos, estas esculturas resultan explícitas también porque su sentido metafórico de semejanza está, en parte, en la imagen misma, la expresividad corporal por sí sola denota un claro estado emocional, pues recurre más claramente a lo que Umberto Eco (1986, p.179) Ilama códigos de reconocimiento, elementos propios del objeto representado que se interpretan con base en la experiencia con la realidad. En este caso, sin embargo, el sentido alegórico no está solo en la expresividad corporal. Las esculturas aparecen siempre fragmentadas, rotas; en esta clara estrategia metafórica de la imagen, el espacio para la interpretación se abre exponencialmente: ¿Por qué están rotas? ¿Qué representan alegóricamente, por un lado, y en tanto objetos en el mundo del relato?

En el surrealismo pictórico, los cuerpos monolíticos fragmentados son un motivo visual recurrente. Salvador Dalí, por ejemplo, en La metamorfosis de Narciso ilustra el clásico mito griego, en el que Narciso se enamora de su propio reflejo en la superficie del agua y se arroja a su muerte, mediante un desdoblamiento en dos figuras pétreas fragmentadas, una que muere y otra que 
resurge a la vida en forma de la flor homónima que crece entre sus grietas. El cuadro es, pues, una representación simbólica, no figurativa, de un proceso emocional.

En el caso de Gris, la representación simbólica de estos cuerpos pétreos se liga también con nociones de fragilidad emocional, aunque de distinta índole, y de una identidad incompleta; vale la pena señalar, incluso, la coincidencia en la aparición de nueva vida en forma de flores surgiendo de las piedras fragmentadas en ambos ejemplos.

Un aspecto trascendental para la interpretación de estos códigos es también el conjunto de sus elementos intertextuales, las referencias artísticas presentes en el lenguaje visual de Gris. La animación del juego está realizada esencialmente a mano, como los dibujos animados tradicionales, que luego es digitalizada para permitir integrarla al código informático. En primera instancia, este tipo de imágenes rompe con los estilos visuales más comunes en la producción de videojuegos actuales, y recuerda más bien a la animación infantil popularizada por Walt Disney a partir de los años 30 del siglo XX. El juego superpone un filtro granulado a las secuencias cinemáticas principales, y, en conjunto con el uso de texturas lisas y planos superpuestos que casi eliminan la profundidad de campo, parece aludir también al estilo del director de animación Chuck Jones, famoso por producir algunos clásicos animados de Warner Bros., así como cortometrajes de ambición cinematográfica de mayor envergadura, como The Dot and the Line (Metro Goldwyn Mayer,1965) y The Bear that Wasn't (Metro Goldwyn Mayer, 1967). Por otra parte, la dirección de arte de Gris a cargo de Conrad Roset, cuya obra general ${ }^{4}$ y su trabajo para este juego se caracterizan por un estilo de colores planos en acuarela, está claramente alimentada por el art nouveau francés de principios de siglo XX, en particular los diseños de Alphonse Mucha, Henri de Toulouse-Lautrec y Théophile Alexandre Steinlen, así como del surrealismo minimalista de Joan Miro, los cuales a su vez son herederos del romanticismo pictórico, el impresionismo y las vanguardias de inicio del siglo en general.

Esta red intertextual, los íconos del surrealismo y las referencias al arte de vanguardia y la animación, forma parte del código para la interpretación de Gris en tanto confiere un "aura"

\footnotetext{
${ }^{4}$ La cual puede revisarse en su página web oficial: https://www.conradroset.com/portfolio
} 
artística al diseño visual. Es posible, desde luego, encontrar o establecer puentes de referencia intertextual a partir de cualquier juego, como lo es en cualquier obra artística o literaria, pues la naturaleza del arte es la intertextualidad; pero juegos cuyas referencias apuntan a una esfera culturalmente asociada con la historia del arte plantearán a los jugadores un horizonte de expectativas categóricamente distinto al de juegos que encuentren sus referencias en otros juegos contemporáneos, o en estilos visuales predominantes en otros medios narrativos populares. ${ }^{5}$ Gris, al aludir a estas expectativas, demanda tácitamente un tipo de interpretación mucho más contemplativa y reflexiva que un juego de tirador en primera persona ambientado en un contexto militar o un juego de carreras automovilísticas en el que la estética visual sea meramente práctica y funcional para los objetivos de la competencia.

La red intertextual conmina a una interpretación no solamente basada en el mero reconocimiento de los signos y símbolos presentados, sino en el propio carácter artístico de los elementos intertextuales traídos a la pantalla y la propuesta visual del juego en sí misma. Las semejanzas establecidas en las metáforas de la estética visual serían pasadas por alto por los jugadores si la red intertextual no los llamara a plantearse una lectura más profunda de su experiencia con el juego.

\section{Demoler y esculpir la identidad}

Sigue descubrir el otro aspecto capital que determina los procesos de interpretación configurados en Gris, la propia narración, y las acciones que el jugador debe llevar a cabo.

Aunque la carga significativa de las imágenes como símbolos sin duda es un rasgo determinante de Gris como obra narrativa, en realidad esos sentidos dispersos en las imágenes son llevados a su última consecuencia en la interpretación a través de la dimensión configurativa de la trama, la cual puede reseñarse de la siguiente manera:

\footnotetext{
${ }^{5}$ Un porcentaje importante de los videojuegos producidos y comercializados en todo el mundo durante los años 90 fue de origen japonés, y recogía notas del diseño de las populares historietas conocidas como manga, y de la animación tradicional japonesa, anime; en la actualidad, incluso juegos de origen no japonés persisten en esa línea de diseño.
} 
Una mujer ${ }^{6}$ que duerme posada sobre la palma de una mano de piedra despierta y comienza a cantar, lo que la hace entrar en un cierto éxtasis. No obstante, al mismo tiempo que la mano de piedra comienza a desmoronarse bajo sus pies, la mujer pierde la voz y se ve impedida para seguir cantando, lo cual se manifiesta en un ataque de confusión y angustia. La mano de piedra se desmorona por completo y la mujer cae al vacío. Cuando llega el fondo de su descenso, se da cuenta de que todos los colores a su alrededor se han desvanecido, y el mundo está apenas delineado por tonos grisáceos. En ese momento el jugador toma control del avatar y la llama a levantarse y caminar, pero unos segundos después ella se desploma y le impide al jugador seguir desplazándose. Luego de unos momentos más, la mujer se levanta de nuevo, permitiendo al jugador finalmente tomar control pleno sobre el personaje. La mujer entonces sigue adelante para encontrar un desierto sobre el que se levantan las ruinas de una ciudad antigua, en la que habitan estatuas de piedra con la figura de mujeres en estado de duelo. Entre estas ruinas encuentra los fragmentos de la mano de piedra que la sostenía mientras cantaba, y en ese momento de su interior brota una ráfaga de color rojo que tiñe el espacio a su alrededor. El desierto se torna rojizo y los contornos de los objetos se vuelven más sólidos, permitiendo a la mujer observar y explorar el espacio. Mientras camina, la mujer encuentra unas luces fatuas como estrellas que comienzan a seguirla, y cuando llega al centro de la ciudad antigua, estas estrellas se elevan para formar una constelación en el cielo.

A partir de ese momento, sin ninguna narración verbal que lo haga explícito, se infiere que el objetivo del juego es devolver uno por uno los colores al mundo y encontrar el resto de las estrellas para completar la constelación. La aventura llevará a la protagonista por distintos parajes y a una confrontación con el único enemigo del juego, un ente oscuro metamórfico que toma la figura de diversos animales y persigue a la mujer en diferentes momentos de su travesía. La identidad de este

\footnotetext{
${ }^{6}$ Dada la ausencia de narración verbal en el juego, nunca se da a conocer un nombre para designar a la protagonista; los periodistas en sus reseñas normalmente se refieren a ella como Gris, dado el título del juego, y los miembros del equipo de Nomada Studio también utilizan ese nombre para referir al personaje en entrevistas y descripciones del juego. Se prefiere para este análisis, no obstante, persistir en el carácter ambiguo del relato visual y no otorgarle un nombre al personaje.
} 
antagonista no queda clara al inicio, pero como todos los elementos visuales de Gris, su significación simbólica se construye conforme se desarrolla el relato, y su identidad final, aunque metafórica y ambigua, se revelará como trascendental.

Gris presenta una narración por demás sencilla de seguir, es casi del todo lineal incluso en los momentos que se le otorga cierta libertad de secuencia en la trama al jugador. Por ejemplo, la cuarta sección del juego, que coloca al avatar en un espacio subacuático que puede explorar más libremente ya que le es posible moverse por el agua sin la restricción de la gravedad, le pide al jugador que colecte cuatro de las estrellas con las que completará la constelación antes de permitirle seguir adelante. Estas cuatro estrellas se encuentran en una serie de grutas unidas por túnenles que se conectan con una cámara central. El jugador comienza esta pequeña misión justo en esa cámara, y puede decidir cuál de los caminos tomará primero. No obstante, esta libertad no tiene injerencia en el desarrollo general de la trama; toda esta sección pude interpretarse, narratológicamente hablando, como un solo episodio o función narrativa, que en la secuencia lógica funcional de las acciones se coloca en un solo punto preciso.

Al desarrollarse la trama se desarrollan también las habilidades del avatar. Una parte importante del desenvolvimiento de los episodios del relato es el descubrimiento de nuevas habilidades, que se manifiestan como nuevas acciones posibles de realizar por parte del jugador, y como metáfora del progreso emocional del personaje principal. Además de caminar y saltar, las dos acciones más recurrentes y necesarias, en cada episodio la mujer necesita descubrir nuevas habilidades para proseguir su camino. En el episodio del desierto rojo, el avatar descubre la habilidad de transformarse en un bloque pesado, con lo que puede mantenerse en pie en las tormentas de arena sin ser arrastrada por el viento, y puede desmoronar objetos frágiles al dejarse caer sobre ellos para despejar un camino o colapsar el techo de estructuras cerradas.

Este aspecto, el descubrimiento de nuevas acciones posibles de realizar por parte del jugador, resulta en especial notable, pues es el que más determinantemente depende del medio por el que se configura esta historia, los videojuegos. Un espectador que vea la pantalla en la que se proyecte una partida de Gris, pero no sea él o ella quién tenga el control en sus manos, podrá no 
solamente enterarse del sentido de la historia, sino que podrá disfrutarla (aunque esto variará con cada individuo, por supuesto) como a una narración audiovisual tradicional, como una película animada; esto se refuerza con la notación que hace Hans-Georg Gadamer en La actualidad de lo bello (1991) al explicar que observar el acto de jugar de otros es un acto inmersivo en sí mismo, y vuelve partícipe al espectador. No obstante, las acciones realizadas por el jugador en sí mismas comportan sentido, por lo que la experiencia de jugar y ver a alguien jugar son esencialmente distintas, como se verá a continuación.

Desde el propio inicio del juego se tiende este puente interpretativo entre interacción e imagen. Cuando el jugador toma por primera vez control sobre el avatar (lo que sucede apenas unos minutos después de dar inicio a la partida y haber mirado la cinemática inicial), es explícito que la mujer está en un estado depresivo, dada su postura corporal y los acontecimientos recién representados. El jugador esperaría tener control directo sobre el avatar independientemente del estado de ánimo intradiegético del personaje; no obstante, esta expectativa se ve inmediatamente quebrantada al desplomarse el cuerpo de la mujer y no permitir el desplazamiento a voluntad del jugador por unos segundos. De esta manera, la acción misma es imbuida de sentido por la configuración del juego: la narración de cierta forma "obliga" al jugador a experimentar el desarrollo emocional del personaje en la pantalla en su propia experiencia al arrebatarle el control directo y volverlo tan incapaz de seguir adelante como al personaje mismo. Así, las acciones del jugador son en sí mismas simbólicas, lo que revela su carácter de signos, y en el caso de Gris, se integran a la general naturaleza metafórica del juego.

De esta naturaleza simbólica son emblema justo las nuevas habilidades aprendidas durante el desarrollo de la trama. Cada sección de la trama del juego puede interpretarse como una de las etapas del proceso del duelo según el célebre modelo psicológico de Elisabeth Kübler-Ross: negación, ira, negociación, depresión y aceptación. De hecho, esto se constata con ciertos elementos de información paratextuales sobre el proceso creativo de Gris a los que se puede acceder una vez que el juego ha sido terminado, de manera similar a los típicos documentales del "detrás de cámaras" contenidos en los formatos de video caseros, DVD, Blu-ray, etc.; de cualquier 
forma, ni conocer esta información o siquiera tener familiaridad con el modelo Kübler-Ross es necesario para interpretar el desarrollo emocional del personaje principal, sino que solo plantean un contexto más amplio en torno al proceso creativo del juego. Tomando esto en cuenta, las habilidades que descubre el avatar en su travesía son símbolos de este desarrollo emocional. Así como para atravesar las cuevas subacuáticas el avatar descubre la habilidad de sumergirse indefinidamente bajo el agua, o para moverse entre las copas de los árboles en el bosque descubre la habilidad de flotar para permanecer más tiempo en el aire, también descubre que es posible seguir adelante en su proceso emocional de redescubrimiento y encontrar nuevas formas de ser y de relacionarse con el mundo, incluso en medio del duelo.

La más significativa de estas habilidades es la última, que es además la única que no es realmente nueva: el canto. Durante todo el juego, el jugador ha tenido a su disposición un botón del control exclusivo para indicar al avatar que cante. Sin embargo, cada vez que se presiona ese botón, el personaje apenas es capaz de exhalar una bocanada de aire que deja entender su incapacidad para entonar el canto. Esto permite inferir un particular sentido en la línea de las acciones como metáforas, que la protagonista está impedida para realizar esta acción tanto como el propio jugador, y que siquiera intentarlo resulta fútil, pese a la siempre latente posibilidad de hacerlo. Pero en la última etapa del relato, una vez que todos los colores han vuelto al mundo, la protagonista recupera su voz, el jugador puede presionar el botón dedicado para la acción de cantar y con ello infundir vida sobre ciertos objetos en el mundo.

Al dotar a estos objetos de vida, se abren nuevas posibilidades de interacción con ellos, necesarias para superar esta última etapa del juego. Pero en cuanto a la significación emotiva de esta acción como símbolo, recuperar la voz y el canto cierra satisfactoriamente el hilo narrativo de la historia, la protagonista ha recuperado eso que había perdido y con ello restituye su identidad.

En este punto de la trama queda nada más devolver el resto de las estrellas a la constelación y descubrir el efecto que ello tendrá en el mundo. Al regresar al centro de la ciudad, la protagonista devuelve las estrellas al cielo, con las que construye una escalera de luz que le permitirá ascender a 
las alturas. Pero en ese momento se revela la forma final del ente oscuro, un rostro de mujer que asemeja al de la propia protagonista.

Esta última representación de la identidad del antagonista permite al jugador arrojar al fin sentido con respecto de aquél en el contexto surrealista de la historia. Precisamente porque su identidad, como todos los demás aspectos del juego, permanece siempre ambigua, no existe una sola interpretación unívoca ${ }^{7}$ sobre la identidad de este agresor; pero la línea más reconocible es la que establece relaciones de semejanza con algún rasgo emocional del personaje principal, por lo que el ente oscuro podría ser una representación de su propio miedo, de su incapacidad de superar sus limitaciones o de los traumas psicológicos que le impiden desarrollar resiliencia; en pocas palabras, su principal enemiga es ella misma.

El ente oscuro devora a la protagonista y la transporta al fondo de un mar negro y viscoso, lo que de inmediato hacer surgir la idea de que ese mar está hecho de la misma materia que el propio ente oscuro. Pero el avatar logra alcanzar la superficie, y haciendo uso de su habilidad más íntima, el canto, llama a la vida a la estatua de la mujer. Los trozos de piedra de la efigie se reincorporan por completo, y logra al fin sostener a la protagonista en su palma sin desmoronarse. El canto se intensifica y hace que el ente oscuro se desvanezca por completo. La estatua lleva a la mujer al centro de la ciudad, y ésta asciende por la escalera de estrellas para desaparecer entre la luz y las nubes.

Vale un último señalamiento con respecto de la naturaleza intertextual de este título a la luz de la trama ya desarrollada por completo. Aunque Roset no menciona alguna alusión al cuento clásico de Hans Christian Andersen "La Sirenita”, algunas coincidencias son lo bastante notables, tanto en lo anecdótico como en lo simbólico, como para al menos sospechar de una influencia. La pérdida de voz de la protagonista de Gris es la más evidente de estas coincidencias. Aunque el personaje de Andersen sacrifica su voz de manera voluntaria en contraste con la pérdida repentina

\footnotetext{
7 Una anécdota interesante al respecto es que, en la conferencia impartida por Conrad Roset en el Japan Weekend Madrid 2019, un participante de la plática le preguntó directamente cuál es el sentido de la historia. Conrad se negó a contestar, argumentando que hacer pública su interpretación del relato como autor menguaría las distintas interpretaciones que cada uno de los jugadores puedan darle en lo individual.
} 
de la voz del avatar, la consecuencia de esta carencia es equivalente en ambos casos, la pérdida de la identidad. También en ambos casos, el proceso para resarcir el daño, despertar el amor del príncipe para luego sacrificarse por él en el cuento, y el viaje de autodescubrimiento y superación del duelo en el juego, comparten puntos importantes. La Sirenita descubre la posibilidad de trascender a un nuevo plano espiritual en las nubes y el viento, mientras el avatar en Gris asciende al cielo y se desvanece entre las nubes una vez que ha alcanzado esa trascendencia al recuperar su voz y conquistar sus miedos. Por último, ambas obras construyen un relato de iniciación (bildungsroman o coming-of-age story, son los términos más tradicionales en literatura para referirse a este tipo de historias), cuyo aspecto simbólico es justamente la consolidación de la identidad como signo de madurez, casi siempre a través de la pérdida o el sacrificio.

Estas coincidencias, además de contribuir a la red de signos intertextuales del juego, permiten encontrar ciertas venias de interpretación que van más allá de lo visual estético hacia lo propiamente literario, y concretamente hacia los temas que obras como la narrativa fantástica de $\mathrm{H}$. C. Andersen articulan alrededor de la niñez. Aunque no está definido con claridad un rango de edad en la audiencia a la que el juego se dirige, y los rasgos físicos del personaje en Gris son deliberadamente inconcretos también en ese aspecto, las relaciones intertextuales señaladas apuntan a la reflexión en torno a la recuperación/construcción de la identidad como una forma de rito de iniciación, y ello además como forma de liberación tras haber sido víctimas de aquello que Beatriz Alcubierre denomina infantilización en su texto "La infantilización del niño" (2016), el despojo de su agencia ante el mundo tanto por factores circunstanciales propios del desarrollo físico-psicológico de los primeros años de vida, como de las presiones sociales e institucionales ejercidas históricamente sobre esta población. Que el jugador sea agente de este proceso en el juego lo coloca en el rol tanto de guía de este desarrollo (paralelamente a la "ayuda sobrenatural" en la jornada del héroe de Joseph Campbell), como de partícipe del proceso mismo. 


\section{Conclusión}

Se ha constatado que no son solamente los símbolos visuales los que comportan una estética surrealista, sino que la propia historia narrada por Gris, en tanto conjunto de acciones estructuradas en una trama, es también simbólica, o más propiamente, alegórica. Debe tomarse en cuenta que este tipo de alegorización no es una característica eminente del surrealismo, sobre todo en su concepción y manifestaciones más tempranas, en las que la libre asociación de imágenes toma formas caóticas más parecidas al collage; sirva de ejemplo el clásico filme surrealista Le chien andalou (1929) de Luis Buñuel, en el que la trama, si bien evidentemente simbólica, no enarbola una alegoría en torno a un tema concreto de manera tan precisa como Gris en torno al duelo y el desarrollo psicológico. ${ }^{8}$ Esta distinción es importante, pues plantea un contraste con cualquier otra narrativa que no pretenda ser alegórica de la misma manera.

Cualquier relato trata sobre temas con distinta aplicabilidad a la realidad del lector, espectador o jugador; en ello consiste el espacio de posibilidad abierto por el texto. Pero esa posibilidad se erige justamente sobre una cierta verosimilitud tangible del mundo construido por el relato, sus espacios y sus personajes como una realidad válida en y para sí misma. Los relatos alegóricos de la naturaleza que comporta Gris no se fundamentan en esta verosimilitud del mundo del relato, sino en su sentido metafórico, en eso que quieren decir a través del acto discursivo que es el texto o, en este caso, el juego. Con ello no se quiere decir que el relato sea solo un accesorio al discurso; si así fuera, sencillamente no habría relato, solo discurso. Pero el mundo del relato sí se manifiesta como menos tangible, menos contenido en sí mismo, y más dependiente de aquello que quiere transmitir como ideas.

Así, es posible concluir que un juego surrealista como Gris está tan emparentado con la poesía y la pintura como con la narrativa literaria o el cine, por lo que los códigos para su interpretación están también en línea con el análisis poético y pictórico, o al menos requieren más

\footnotetext{
8 Pero la alegoría sí puede estar presente tanto en cuadros como en filmes surrealistas; 81/2 (1963), de Federico Fellini, aunque con un tono casi tan ambiguo como el de Buñuel, sí que construye una alegoría entre la identidad del protagonista y la industria cinematográfica.
} 
patentemente de estas herramientas que otras narraciones que develan un sentido más explícito y figurativo.

La dimensión de la configuración a partir de las acciones del jugador se ha manifestado también como metafórica simbólica. Una crítica recurrente que se hace a Gris entre las reseñas realizadas en el ámbito del periodismo de videojuegos es que la parte de la jugabilidad (gameplay) es su aspecto más endeble, en tanto no propone nada radicalmente novedoso para el género de plataformas en dos dimensiones, si bien su nivel de ejecución resulta sobresaliente en lo técnico (Skill Up, 2018). Y efectivamente; el propio Roset admite que algunas pruebas a lo largo del juego pueden parecer nada más que trámite para marcar los requerimientos de un título de este tipo. Sin embargo, dado el énfasis en los otros aspectos significativos del juego, y la carga simbólica ya explorada de las acciones del jugador, se concluye que estas pruebas y obstáculos se integran a la intencionalidad general de Gris: la historia relata el proceso de desarrollo y superación emocional del duelo, y las pruebas de destreza y acertijos que el jugador debe superar a través del avatar simbolizan esa travesía, el esfuerzo interno del personaje que el jugador comparte a través del control y su propio esfuerzo físico y mental, por nimio que puedan parecer a cada jugador en lo particular. El hecho de que las reglas del juego no prevén un estado de fallo, es decir, no es posible "perder el juego" por fallar o "morir", como en los juegos de plataformas clásicos, es significativo en sí mismo: en el juego, como en el duelo, siempre es posible seguir adelante.

\section{Referencias}

Alcubierre, B. (2016). La infantilización del niño. En A. Villegas, N. Talavera y R. Monroy (coords.), Figuras del discurso: exclusión, filosofía y política (pp.321-343). México: Bonilla Artiga Editores.

Barreiro, B. (2014, septiembre). La estética surrealista [versión electrónica]. En Eikasia: Revista de Filosofía (Núm. 58, pp.447-461).

Beristáin, H. (1995). Diccionario de retórica y poética. México: Editorial Porrúa.

Bobes, C. (2004). La metáfora. Madrid: Gredos. 
Bretón, A. (2001). Manifiestos del surrealismo. Buenos Aires: Argonauta.

Chatman, S. (2013). Historia y discurso: la estructura narrativa en la novela y en el cine. Barcelona: RBA Libros.

Eco, U. (1986). La estructura ausente. Barcelona: Lumen.

Gadamer, H. (1991). La actualidad de lo bello. Barcelona: Paidós.

Gris (Versión para Nintendo Switch) [Videojuego]. (2018). Barcelona: Devolver Digital.

Peirce, C. (1986). La ciencia de la semiótica. Buenos Aires: Ediciones Nueva Visión, 1986.

Peñuela, E. (2006, septiembre). La metáfora visual [versión electrónica]. En Anàlisi: Quaderns De Comunicació I Cultura (Núm. 14, p.69-86).

Ricoeur, P. (2002). Del texto a la acción: ensayos de hermenéutica II. México: Fondo de Cultura Económica.

Ricoeur, P. (2004). Tiempo y narración (Vol. I). México: Siglo XXI.

Skill Up. (2018, 13 de diciembre). Gris - A Brief Review [Archivo de video]. YouTube.

https://www.youtube.com/watch?v=PehrCkdrfd8

Wellek, R. y Warren A. (1966). Teoría literaria. Madrid: Gredos, 1966. 